\title{
The piRNA pathway responds to environmental signals to establish intergenerational adaptation to stress
}

Tony Belicard ${ }^{1,2}$, Pree Jareosettasin ${ }^{1,2}$ and Peter Sarkies ${ }^{1,2^{*}}$ (D)

\begin{abstract}
Background: piRNAs have a constitutive role in genome defence by silencing transposable elements in the germline. In the nematode Caenorhabditis elegans, piRNAs also induce epigenetic silencing of transgenes, which can be maintained for many generations in the absence of the piRNA pathway. The role of multi-generational epigenetic inheritance in adaptation to the environment is unknown.
\end{abstract}

Results: Here, we show that piRNA biogenesis is downregulated in response to a small increase in temperature. Some effects on gene expression persist into subsequent generations and are associated with a negative fitness cost. We show that simultaneous infection with pathogenic bacteria suppresses downregulation of the piRNA pathway in response to increased temperature. This effect is associated with increased fitness of progeny of infected animals in subsequent generations.

Conclusions: Our results show that the piRNA pathway integrates inputs from the environment to establish intergenerational responses to environmental conditions, with important consequences for the fitness of the subsequent generation.

\section{Background}

In animals, the physical separation of germline and soma, established early in development, is believed to result in the Weismann barrier whereby hereditary information moves only from genes to body cells. However, this barrier is not absolute: a growing number of studies have shown that information may be transferred from soma to germline, triggering epigenetic responses that last for multiple generations. By convention, these phenomena are defined as transgenerational when the response is observed after two or more generations (F2 individuals) and responses observed in the first generation (F1) are known as intergenerational [1]. Often, these effects result from exposing animals to stressful conditions. For instance, bacterial infection of Tribolium castanatum can increase resistance of progeny [2], and in mice, severe maternal undernutrition can result in the

\footnotetext{
* Correspondence: psarkies@imperial.ac.uk

${ }^{1} \mathrm{MRC}$ London Institute of Medical Sciences, Du Cane Road, London W12 ONN, UK

${ }^{2}$ Institute of Clinical Sciences, Imperial College London, Hammersmith Hospital Campus, Du Cane Road, London W12 ONN, UK
}

development of insulin resistance in subsequent generations [3]. The nematode Caenorhabditis elegans has been developed as a model to explore molecular mechanisms of multi-generational epigenetic responses to stress. Experiments using starvation [4] or heat stress [5, 6] demonstrated that environmental alterations result in long-term perturbation of gene expression corresponding to the accumulation of small silencing RNAs targeted to specific genes, which persist in the absence of the environmental trigger. However, how environmental perturbations signal to small RNA pathways, including how the germline-soma barrier is crossed, is still unknown.

Any molecular mechanism that accounts for epigenetic phenomena triggered by stress must fulfil two properties: it must be active in the germline thus able to transmit its effects into the next generation, and its activity must be modulated in response to specific signals from the soma. These considerations suggest that the Piwi-interacting small RNA pathway may be a candidate for transmitting epigenetic information. Piwi-interacting small RNAs are 21-33 nt RNAs produced from 
single-stranded precursor RNAs, which interact with the Piwi family of Argonaut proteins to bring about target recognition and silencing [7]. piRNAs are widely conserved across eukaryotic organisms and are characteristically enriched in the germline where they are often involved in silencing transposable element (TE) expression [7]. In most organisms studied so far, piRNAs are essential for fertility, either directly linked to their TE suppression function or through other, less well-understood roles in germline stem cell maintenance [8].

The functions attributed to the piRNA pathway means that it has typically been considered as constitutive, essential to maintain genome integrity against TE-derived mischief. Nevertheless, the silencing triggered by piRNAs establishes transgenerational effects [9-12]; thus, mechanistically they have the potential to act in transmission of signals from soma through the germline into the next generation. However, it is unknown whether silencing triggered by the piRNA pathway can respond dynamically to the environment; thus, the relevance of piRNAs to stress-induced multi-generational epigenetic phenomena is still unclear. Here, we use the model nematode C. elegans to explore environmental regulation of piRNAs.

In C. elegans, the bulk of piRNAs are produced from individual loci in two clusters on Chromosome IV, each demarcated by a GTTTC consensus motif [13-15]. These motif-dependent piRNAs are dependent on the RNA pol III factor gei-11/snpc-4 [16] and the dedicated piRNA biogenesis gene prde-1 [17]. In addition, a smaller number of motif-independent piRNAs are found scattered through the genome, which do not depend on prde-1 for their function and for which specific biogenesis factors are still unknown [17, 18]. Despite distinct biogenesis, both types of piRNAs bind to the piwi protein prg-1 [18] and induce target silencing through recruitment of RNA-dependent RNA polymerases for 22G-RNA production [17]. Motif-dependent and motif-independent piRNAs target different sets of genes: whilst motif-dependent piRNAs target transposable elements and poorly conserved genes with few clear functions, motif-independent piRNA targets are strongly enriched for innate immune genes [17].

Transgenes subjected to piRNA-induced silencing demonstrated that once established, the silent state is maintained for multiple generations in the absence of piRNAs $[9-11,19]$. Some endogenous genes targeted by piRNAs are also subject to transgenerational silencing maintained in the absence of piRNAs [20, 21]. Although the mechanism underlying this process is largely understood, what is missing is a coherent account of whether the process is responsive to changes in environmental conditions and thus whether the piRNA pathway might account for transgenerational epigenetic effects important for the natural lifecycle of $C$. elegans.

Here, by investigating the strength of piRNA-dependent silencing in response to different temperatures, we find that motif-dependent piRNA biogenesis is reduced by a moderate increase in temperature from 20 to $25{ }^{\circ} \mathrm{C}$. A subset of gene expression changes induced by this shift persists into subsequent generations after returning to $20^{\circ} \mathrm{C}$. Additionally, we find that the fitness of the progeny of animals grown at $25{ }^{\circ} \mathrm{C}$ is reduced relative to the progeny of animals grown at $20{ }^{\circ} \mathrm{C}$. Intriguingly, infection with pathogenic bacteria suppresses the reduction in motif-dependent piRNAs and increases the fitness of progeny relative to the progeny of uninfected animals. Together, our data suggest that piRNAs respond dynamically to environmental stimuli, modifying gene expression and impacting the fitness of subsequent generations.

\section{Results}

Downregulation of motif-dependent piRNA biogenesis in response to increased temperature

To test the effect of environmental conditions on piRNA-mediated silencing, we used a strain of $C$. elegans with a germline-expressed GFP transgene with a perfect target site for a specific motif-dependant piRNA in its 3' UTR [22]. The piRNA sensor is silenced in wild-type worms at $20{ }^{\circ} \mathrm{C}$ whilst mutants lacking either prde-1 or prg-1 desilence the piRNA sensor at $20{ }^{\circ} \mathrm{C}$, indicating that the activity of the piRNA pathway is required for sensor silencing [23] (Fig. 1a).

Whilst the piRNA sensor is completely silenced in wild-type animals at $20{ }^{\circ} \mathrm{C}$, when grown at $25{ }^{\circ} \mathrm{C}$, the GFP signal became visible in most animals $(p<0.001)$ indicating desilencing of the piRNA sensor (Fig. 1b). A temperature gradient between $20{ }^{\circ} \mathrm{C}$ and $26^{\circ} \mathrm{C}$ indicated a switch in piRNA silencing above $22.5^{\circ} \mathrm{C}$ above which notable silencing could be observed (Fig. 1c). Expression of the piRNA sensor was not increased by temperature in prde-1 or prg-1 mutants that lack a functional piRNA pathway, thus confirming that the increased expression of the sensor is due to compromised piRNA-mediated silencing at higher temperature.

To investigate the mechanism of reduced piRNA silencing, we undertook small RNA sequencing from animals grown at $20{ }^{\circ} \mathrm{C}$ or $25^{\circ} \mathrm{C}$. We used standard hypochlorite treatment to obtain large numbers of embryos and after hatching to L1s at $20{ }^{\circ} \mathrm{C}$, we grew animals to young adult stage at either $20^{\circ} \mathrm{C}$ or $25^{\circ} \mathrm{C}$ before isolating RNA for small RNA library preparation (see the section "Methods"). Mature piRNA levels, normalised to total 18-33 nucleotide long small RNAs (see the section "Methods"), derived from motif-dependent loci were reduced at $25{ }^{\circ} \mathrm{C}(p<1 \mathrm{e}-16$, Wilcox unpaired test; Fig. 1d). Competition between small RNA pathways in C. elegans 
A

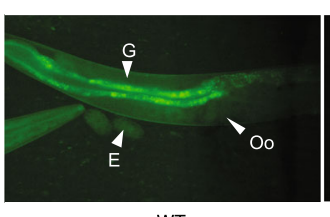

WT

\section{D}

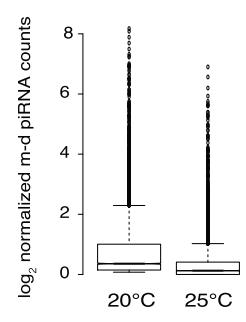

B

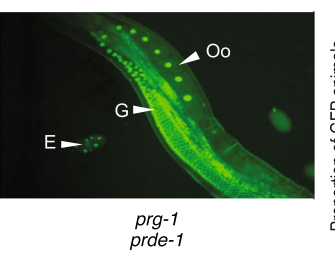

E

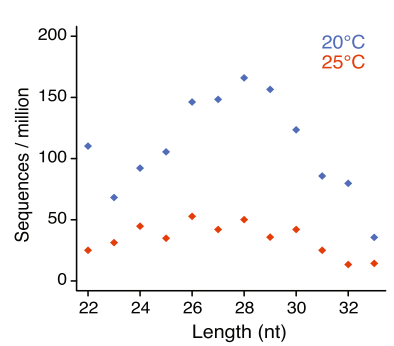

C

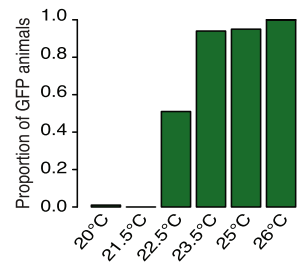

Fig. 1 Reduction in motif-dependent piRNA biogenesis at increased temperature. a Expression of GFP in nuclei of the gonad (G), oocytes (Oo) and eggs (E) of animals carrying the piRNA sensor at $20^{\circ} \mathrm{C}$ in the wild-type strain (WT, left), and in mutants for the piRNA pathway (prg-1 and prde-1, right). $\mathbf{b}$ Proportion of wild-type animals expressing GFP at $20^{\circ} \mathrm{C}$ and $25^{\circ} \mathrm{C}$. At least 30 worms have been screened for each conditions in each of the 4 replicates $\left(20^{\circ} \mathrm{C} n_{\text {total }}=138,25^{\circ} \mathrm{C} n_{\text {total }}=208\right.$, two-sided Student's $t$ test). Animals were grown at the tested temperature for their entire developmental cycle (i.e. from fertilisation to adulthood). c Proportion of wild-type animals expressing $\mathrm{GFP}$ at $20{ }^{\circ} \mathrm{C}(\mathrm{n}=75)$, $21.5^{\circ} \mathrm{C}$ $(n=50), 22.5^{\circ} \mathrm{C}(n=45), 25^{\circ} \mathrm{C}(n=89)$ and $26^{\circ} \mathrm{C}(n=49) . \mathbf{d} \log _{2}$ motif-dependent piRNA counts normalised to the total number small RNAs in the wild-type strain at $20^{\circ} \mathrm{C}$ and $25^{\circ} \mathrm{C}$. Animals were grown at the tested temperature from the first larval stage to adulthood. 18,571 piRNA loci with a motif score $>7$ according to the algorithm used in Ruby et al. [15] were examined. e Abundance of piRNA precursors (26 to 30 nt) in the wild-type strain at $20^{\circ} \mathrm{C}$ and $25^{\circ} \mathrm{C}$. piRNA precursors from any of the 18,571 loci as above were examined

has been well documented [24-26]. We therefore investigated how other small RNA pathways respond to temperature. 22G-RNAs showed no change at $25{ }^{\circ} \mathrm{C}$ relative to $20{ }^{\circ} \mathrm{C}$ (Additional file 1: Figure S1A). miRNAs showed a small but significant increase at $25{ }^{\circ} \mathrm{C}$ (Additional file 1: Figure S1B); however, the change was less statistically significant than the reduction in piRNAs (Additional file 1: Figure S1A). Additionally, the reduction in motif-dependent piRNAs was robust to different normalisation methods (Additional file 1: Figure S1C). Thus, we conclude that the increased temperature likely affects the piRNA pathway directly.

We next investigated the mechanism accounting for reduced mature piRNA levels. One possible mechanism would be reduced prg-1 protein levels, which has been observed previously at $25{ }^{\circ} \mathrm{C}$ [13]. However, since prg-1 protein is reduced in the absence of $21 \mathrm{Us}$ [23], this could be a consequence rather than a cause of reduced piRNAs. Consistent with this interpretation, we saw no consistent change in prg- 1 transcript levels at $25^{\circ} \mathrm{C}$ relative to $20{ }^{\circ} \mathrm{C}$ (Additional file 2: Figure S2E). An alternative explanation for reduced piRNA levels could be an effect on piRNA biogenesis. We therefore investigated piRNA precursors, which are capped 26-30 nt long small RNAs with a 2' 5 -extension relative to the mature 21U-RNA [17, 18, 27]. piRNA precursors were strongly reduced at $25{ }^{\circ} \mathrm{C}$ (Fig. 1e). Moreover, motif-independent
piRNAs, which bind to $p r g-1$ but which are produced independently of prde-1 $[17,18,28,29]$, were not significantly reduced at $25{ }^{\circ} \mathrm{C}$ (Additional file 1: Figure S1D). Importantly, we tested whether this was due to reduced power to detect differences in motif-independent piRNAs due to their lower abundance by downsampling motif-dependent piRNA numbers to the number of motif-independent piRNAs detected. We detected a significant reduction $(p<1 \mathrm{e}$ -16) in motif-dependent piRNAs in all samples and the difference was significantly larger than the difference in motif-independent piRNAs in every sample (Additional file 1: Figure S1E and F). Thus, we conclude that the reduction in motif-dependent piRNAs at $25{ }^{\circ} \mathrm{C}$ is due to reduced piRNA biogenesis. Intriguingly, we observed the same response in piRNA biogenesis for two other nematode species Pristionchus pacificus (Additional file 2: Figure S2A and B) and Caenorhabditis briggsae (Additional file 2: Figure $\mathrm{S} 2 \mathrm{C}$ ) when shifted from 20 to $25{ }^{\circ} \mathrm{C}$, despite the fact that $C$. briggsae has a higher optimal growth temperature than $C$. elegans and suggesting that the temperature-dependent response is widely conserved.

\section{Temperature induces intergenerational reduction in piRNA-mediated silencing}

The ability of environmental perturbations to affect the piRNA pathway provides an example whereby 
environmental conditions can be either sensed directly by the germline or communicated to the germline from the soma. As piRNAs can initiate transgenerational epigenetic alterations, the effects of perturbations may remain once the environmental perturbations have been removed. To test this, we used RNAseq to investigate gene expression in animals grown at either $20^{\circ} \mathrm{C}$ or $25^{\circ} \mathrm{C}$. We first isolated RNA from nematodes at the onset of egg-laying at both temperatures and identified differentially expressed genes. However, many C. elegans genes oscillate throughout developmental time, and the changes we detected were dominated by changes in such variable genes suggesting that subtle differences in developmental stage between animals grown at different temperatures might be responsible for these changes. In order to avoid this, we isolated RNA in duplicate from young adult worms 8,16 and $24 \mathrm{~h}$ after the visually distinctive fourth larval moult (L4 stage) at both $20{ }^{\circ} \mathrm{C}$ and $25{ }^{\circ} \mathrm{C}$ and searched for gene expression changes that were consistently regulated across all three timepoints. This identified 37 genes that were consistently affected across different timepoints (Fig. 2a; Additional file 3: Table S1; Additional file 4: Figure S3a).

To test the involvement of the piRNA pathway, we sequenced small RNAs from C. elegans grown at $20{ }^{\circ} \mathrm{C}$ or $25^{\circ} \mathrm{C}$. Direct targets of piRNAs are complicated to predict due to imperfect complementarity $[10,22]$ and the possibility of transgenerational epigenetic memory meaning that certain genes are no longer dependent on piRNA recognition [20, 21]. We therefore mapped 22G-RNAs, the effectors of piRNA-mediated silencing, to genes [22] and examined the changes in small RNAs on genes with consistent expression changes at $25^{\circ} \mathrm{C}$ relative to $20{ }^{\circ} \mathrm{C}$. Genes that were consistently upregulated all showed a significant decrease in small RNA levels $(p<0.01$; Fig. $2 \mathrm{~b})$. However, genes that were downregulated did not show upregulated small RNAs. This suggested that loss of piRNA-mediated silencing might result in upregulation of genes due to loss of 22G-RNAs, but that downregulation of genes was not a direct result of piRNA changes.

To further examine the role of the piRNA pathway in temperature-mediated gene expression changes, we compared the set of genes identified with gene expression changes identified in prde-1 mutants lacking motif-dependent piRNAs. Genes upregulated at $25{ }^{\circ} \mathrm{C}$ showed a statistically significant overlap with genes upregulated in prde-1 mutants at $20{ }^{\circ} \mathrm{C}$ relative to $\mathrm{N} 2$ (Fig. 2c and Additional file 4: Figure S3B), consistent with downregulation of piRNAs at increased temperature (Fig. 1).

We next investigated gene expression changes in the progeny of animals raised at either $25{ }^{\circ} \mathrm{C}$ or $20{ }^{\circ} \mathrm{C}$ after return to $20{ }^{\circ} \mathrm{C}$. There was significant overlap between genes upregulated at $25{ }^{\circ} \mathrm{C}$ in $\mathrm{P} 0$ animals and genes
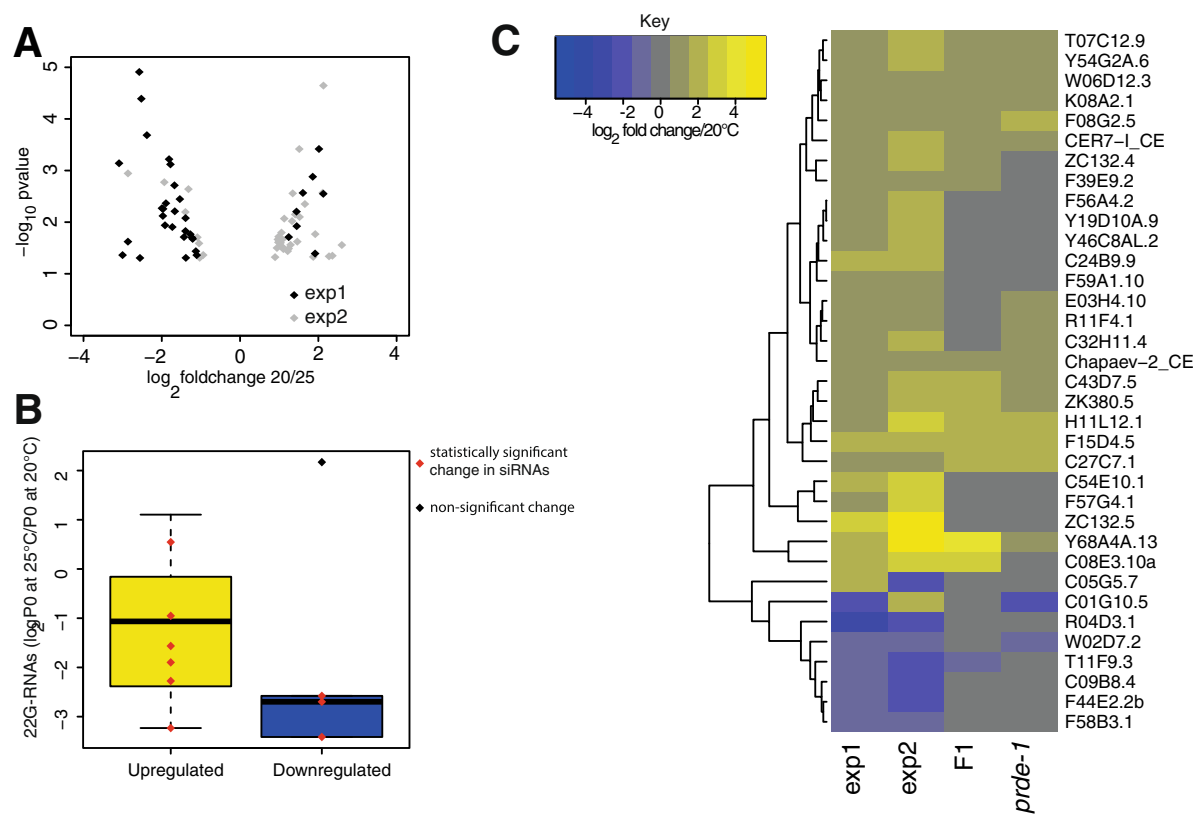

Fig. 2 Intergenerational gene expression alterations induced by increased temperature. a Volcano plot presenting the overlap of downregulated genes ( $\log _{2}$ fold change $\left.20^{\circ} \mathrm{C} / 25^{\circ} \mathrm{C}<0\right)$ and upregulated genes $\left(\log _{2}\right.$ fold change $20^{\circ} \mathrm{C} / 25^{\circ} \mathrm{C}>0$ ) at $25^{\circ} \mathrm{C}$ between adults $\mathrm{PO}$ animals (exp1) and the time course experiment (exp2). $\mathbf{b}$ Changes in secondary piRNA production for upregulated genes (yellow) and downregulated genes (blue) at $25^{\circ} \mathrm{C}$ compared to $20^{\circ} \mathrm{C}$ for the overlapping genes from exp1 and exp2. c Heatmap representing the behaviour of these genes for P0 at $25^{\circ} \mathrm{C}$ (exp1), the time course experiment at $25^{\circ} \mathrm{C}$ (exp2), $\mathrm{F} 1$ grown at $20^{\circ} \mathrm{C}$ from P0 grown at $25^{\circ} \mathrm{C}$ (F1) and prde-1 mutant animals. Numbers of genes involved are shown in Additional file 4: Figure S3A, B and C 
upregulated in F1 animals derived from parents grown at $25{ }^{\circ} \mathrm{C}$ (Fig. 2c and Additional file 4: Figure S3C). The majority of these shared genes were also upregulated in prde-1 mutants (Fig. 2c and Additional file 4: Figure S3C), supporting a causal role for the piRNA pathway in the regulation of these genes.

\section{Intergenerational epigenetic inheritance influences adaptation to temperature}

To investigate potential consequences of transgenerational epigenetic changes induced in response to temperature, we carried out competition experiments at $20^{\circ} \mathrm{C}$ between the progeny of animals grown at $20^{\circ} \mathrm{C}$ or $25^{\circ} \mathrm{C}$, using either an introgression from the C. elegans strain JU1580 (mfIR41(IV,JU1580>N2), using a single nucleotide polymorphism (SNP) WBVar01650008 as a marker) into the laboratory strain N2 or a GFP as markers (Fig. 3a and Additional file 5: Table S2). F1 animals derived from parents grown at $20{ }^{\circ} \mathrm{C}$ outcompeted animals from parents grown at $25{ }^{\circ} \mathrm{C}$ in both experiments (Wilcox test; $p<0.05$ for F2/3 Fig. 3b; $p=0.1$, smallest $p$ value possible for $n=3$, for F2/3 Fig. 3c, and Additional file 5: Table S2, also see Additional file 6: Figure S4C for further generations). However, $\mathrm{F} 1$ animals derived from parents grown at $25^{\circ} \mathrm{C}$ do not outcompete $\mathrm{F} 1$ animals derived from parents grown at $20^{\circ} \mathrm{C}$ when $\mathrm{F} 1 \mathrm{~s}$ are grown at $25^{\circ} \mathrm{C}$ (Wilcox test; $p>0.5$ for F2/3, Additional file 6: Figure S4A and B). Thus, growth at $25{ }^{\circ} \mathrm{C}$ leads to reduced fitness of subsequent generations at $20^{\circ} \mathrm{C}$ without improving the fitness of subsequent generations at $25^{\circ} \mathrm{C}$, at least when grown on $E$. coli as a food source within the laboratory.

\section{Bacterial infection restores motif-dependent piRNA levels at increased temperatures}

Whilst undergoing experiments to test the effect of temperature on piRNA silencing, we noticed anecdotally that occasional contamination of plates with non- $E$. coli bacteria, which impaired growth of $C$. elegans, resulted in lack of induction of the sensor at $25{ }^{\circ} \mathrm{C}$. miRNAs have been implicated in pathogen responses [30,31] and, anecdotally, to impact on knockdown of genes by RNAi [32]. We therefore wondered whether infection of nematodes with pathogenic bacteria had any effect on silencing by the piRNA pathway. C. elegans has been used frequently to model infection with pathogenic bacteria; we therefore decided to use the piRNA sensor to test whether such infections had any affect on piRNA-mediated silencing. We infected animals grown at $25{ }^{\circ} \mathrm{C}$ with virulent Pseudomonas aeruginosa (PA14) or an attenuated strain (PAK) and compared to animals grown on E. coli. Whilst the sensor was induced as expected at $25^{\circ} \mathrm{C}$ when grown on PAK or E.coli, animals grown on PA14 retained piRNA sensor silencing $(p<0.05$, Fisher's exact test Fig. $4 \mathrm{a}, \mathrm{b}$, Additional file 7: Table S3). Similarly, infection with other known C. elegans bacterial pathogens Serratia marcescens (DB11) and the less virulent Photorhabdus luminescens (PL), resulted in increased piRNA sensor silencing relative to uninfected control animals (both $p<0.05$, Fisher's exact test; Fig. 4b). The increased silencing of the piRNA sensor induced by infection was dependent on the piRNA pathway because infection of either prg-1 or prde-1 did not lead to sensor silencing (Fig. 4a, b).

We next sequenced piRNAs from $\mathrm{F} 1$ animals grown at $20^{\circ} \mathrm{C}$ derived from parents either grown at $20^{\circ} \mathrm{C}, 25^{\circ} \mathrm{C}$ or at $25^{\circ} \mathrm{C}$ on $\mathrm{S}$. marcescens. Importantly, $\mathrm{F} 1$ animals derived from parents grown at $25^{\circ} \mathrm{C}$ show reduced levels of mature piRNAs compared to $\mathrm{F} 1$ animals derived from parents grown at $20{ }^{\circ} \mathrm{C}$ (Fig. 4c). This suggests that the reduction in piRNAs observed as a result of growth at $25^{\circ}$ $\mathrm{C}$ persists in their progeny despite return to $20^{\circ} \mathrm{C}$. However, mature piRNA levels were higher in F1 animals derived from parents infected with $S$. marcescens than from uninfected parents, indicating that growth at $25^{\circ} \mathrm{C}$ with $S$. marcescens suppressed the reduction in piRNA levels in F1 animals ( $p<0.001$, Wilcoxon paired test).

To test how this related to changes in gene expression, we carried out RNAseq on the F1 animals derived from infected animals grown at $25{ }^{\circ} \mathrm{C}$ and compared to $\mathrm{F} 1$ animals derived from uninfected controls grown at $25{ }^{\circ} \mathrm{C}$. Both sets of $\mathrm{F} 1$ animals were returned to $20{ }^{\circ} \mathrm{C}$. Genes previously identified as upregulated at $25{ }^{\circ} \mathrm{C}$ (Fig. 2) remained upregulated in $\mathrm{F} 1$ animals derived from uninfected controls (Fig. 4d), consistent with the intergenerational effect of gene expression changes that we observed previously (Fig. 2) and consistent with our observation that piRNA levels are reduced in these F1 animals. However, genes upregulated at $25{ }^{\circ} \mathrm{C}$ were no longer upregulated in progeny of animals infected with S. marcescens. Thus, bacterial infection suppressed intergenerational changes in gene expression. Importantly, the effect was statistically stronger in the subset of temperature-sensitive genes that are also upregulated in prde- 1 animals than in genes that are not upregulated in prde-1 (Fig. 4e, Additional file 8: S5A and S5B), suggesting that the intergenerational upregulation of these genes is due to reduced piRNA levels.

Taken together, our results demonstrate that bacterial infection suppresses intergenerational gene expression changes induced by growth of parent animals at $25{ }^{\circ} \mathrm{C}$ by suppressing the reduction in piRNA levels that occurs at this temperature.

\section{Bacterial infection improves fitness intergenerationally}

We wondered what the functional consequences of piRNA pathway modulation by bacterial infection might be. We first tested whether increased piRNA levels induced by bacterial infection might affect susceptibility to infection. Prde-1 mutants, which lack motif-dependent piRNAs [17], 
A

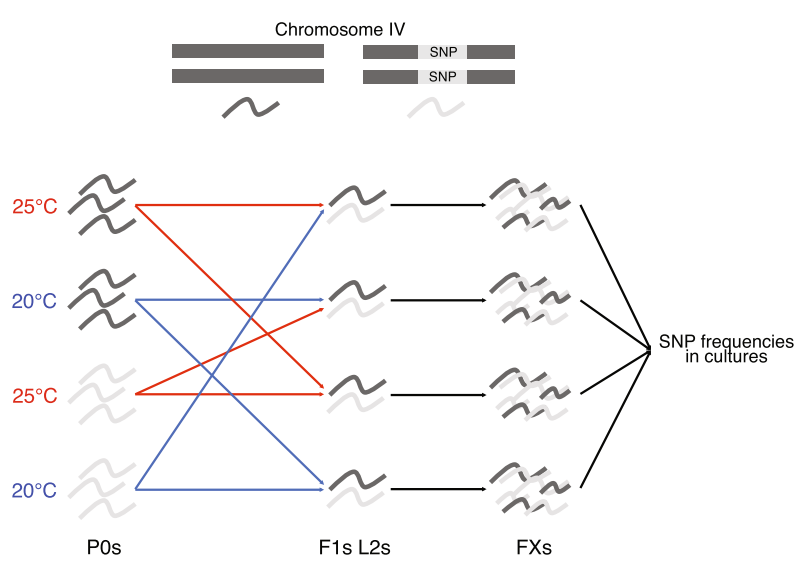

B

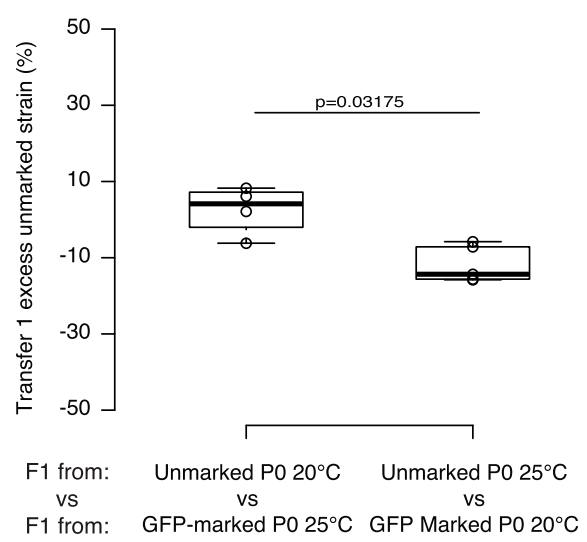

C

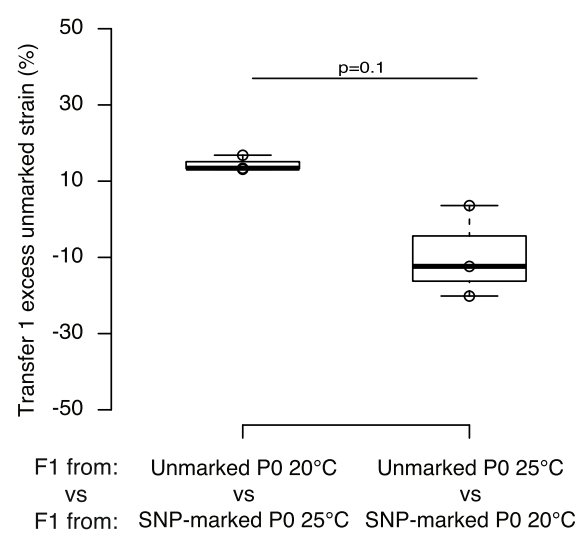

Fig. 3 Intergenerational fitness effects of growth at altered temperatures. a Experimental design used for the competition assay. Two strains with either different fluorescence (unmarked or GFP-marked) or different genotypes (N2 or N2 containing introgressed SNPs from JU1580 on Chromosome IV) were grown at $20^{\circ} \mathrm{C}$ or $25^{\circ} \mathrm{C}$ and then synchronised using sodium hypochlorite treatment (bleaching). Equal number of F1s from two different parental treatments was then put in the same plate. All different combinations have been tested in parallel either in triplicate or in quintuplicate. Before starvation, animals were harvested and the proportions of each of the different strains measured using a fluorescent microscope (GFP-marked animals) or using pyrosequencing (SNP-marked animals). 200 to 400 animals were transferred to a fresh NGM plate and the proportions were measured similarly. $\mathbf{b}$ Intergenerational competition at $20^{\circ} \mathrm{C}$ between animals derived from (left) unmarked P0 animals grown at $20^{\circ} \mathrm{C}$ and GFP-marked P0 animals grown at $25^{\circ} \mathrm{C}$; (right) GFP-marked P0 animals grown at $20{ }^{\circ} \mathrm{C}$ and unmarked P0 animals grown at $25^{\circ} \mathrm{C}$. c Competition at $20^{\circ} \mathrm{C}$ between animals derived from (left) unmarked PO animals grown at $20^{\circ} \mathrm{C}$ and SNP-marked P0 animals grown at $25^{\circ} \mathrm{C}$; (right) SNP-marked P0 animals grown at $20^{\circ} \mathrm{C}$ and unmarked P0 animals grown at $25^{\circ} \mathrm{C}$. $Y$-axes show the proportion of unmarked animals after 1 transfer for all replicates, corrected for the effect of the SNP or the GFP by subtracting the mean of the proportions of animals grown at $20{ }^{\circ} \mathrm{C}$ when both P0 strains were grown at $25^{\circ} \mathrm{C}$. The raw data are available in Additional file 5: Table S2

showed the same sensitivity to infection with $S$. marcescens as wild-type $C$. elegans, indicating that piRNAs do not directly contribute to resistance to this pathogen $(p>0.1$ Maental-Hutzel log test for interaction between prde-1 and S. marcescens; Fig. 5a and Additional file 9: Table S4). Since bacterial infection suppresses temperature-dependent intergenerational changes in piRNAs and gene expression, we hypothesised that bacterial infection might similarly suppress intergenerational fitness defects resulting from growth at $25{ }^{\circ} \mathrm{C}$. Consistent with this hypothesis, progeny of DB11-infected animals outcompeted progeny of uninfected animals when both were grown at $20{ }^{\circ} \mathrm{C}$ (Fig. 5b, c, $p<0.05$, Wilcoxon unpaired test, further generations see Additional file 6: Figure S4D). Thus, the fitness of animals is improved by infection of the previous generation with pathogenic bacteria.

\section{Discussion}

Despite much interest in multi-generational epigenetic phenomena in many model systems, including C. elegans, little is known of what role this might have in the lifecycle of animals in the wild. Our study offers two 


\section{B}

A
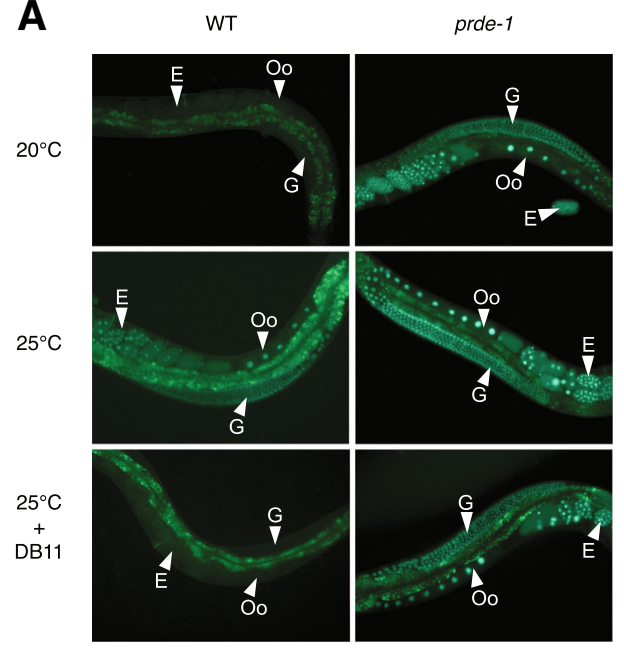

D

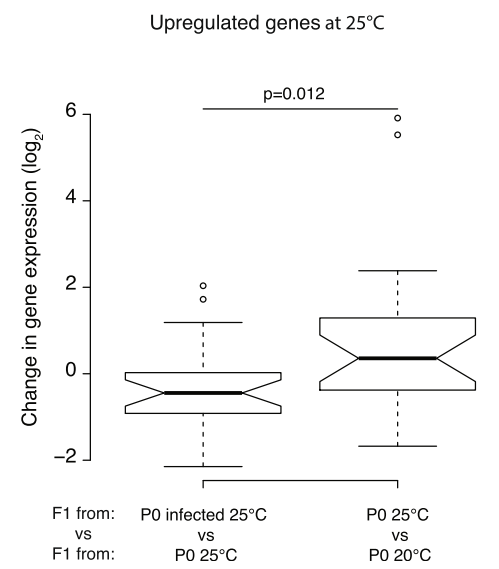

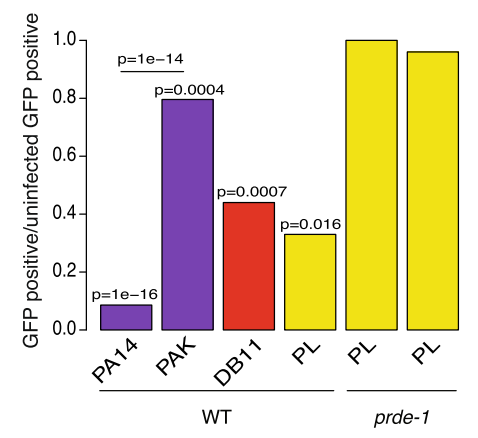

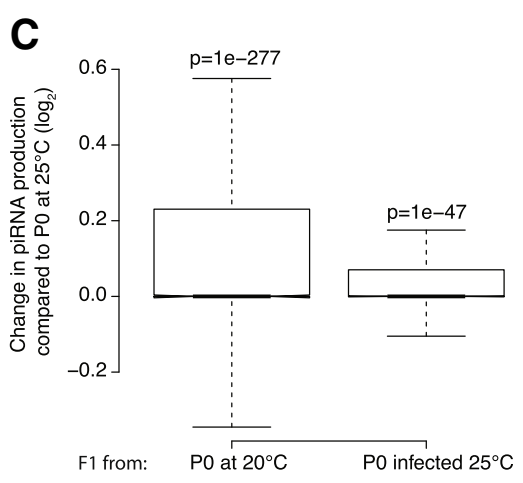

E Genes upregulated at $25^{\circ} \mathrm{C}$

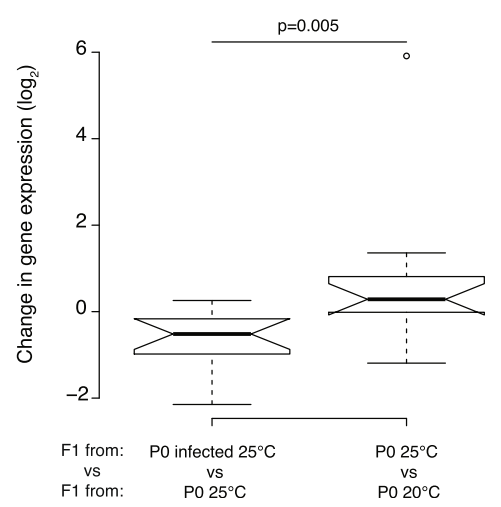

Fig. 4 Bacterial infection suppresses reduced piRNA levels at $25^{\circ} \mathrm{C}$. a Expression of GFP in nuclei of the gonad (G), oocytes (Oo) and eggs (E) of animals carrying the piRNA sensor in the wild-type strain (WT, left) and in the prde-1 mutant (prde-1 right) both grown from hatching either at $20{ }^{\circ} \mathrm{C}$ or $25^{\circ} \mathrm{C}$ on regular bacteria (HB101) or at $25^{\circ} \mathrm{C}$ on the pathogenic bacteria Serratia marcescens (DB1 1). b Proportion of wild-type animals (WT) and prde- 1 animals expressing GFP on: $P$. aeruginosa (purple) PA14 (high toxicity, $n=47$ ) and PAK (low toxicity, $n=73$ ); . marcescens DB11 (red, $n=106$ ); and P. luminescens (yellow; WT $n=31$; prg-1 $n=28$; prde- $1 n=46$ ) relative to the proportion of GFP-positive animals grown at $25{ }^{\circ} \mathrm{C}$ on regular food ( $n=38$ ). Fisher's exact test was used to evaluate differences between conditions. Raw data are available in Additional file 9: Table S4. c Change (Log 2 ) in mature piRNA levels in F1s from parents grown at $20^{\circ} \mathrm{C}$ ( $\mathrm{PO}$ at $20^{\circ} \mathrm{C}$ ) or grown at $25^{\circ} \mathrm{C}\left(\mathrm{PO}\right.$ at $\left.25^{\circ} \mathrm{C}\right)$ in presence of Serratia marcescens compared to $\mathrm{F} 1 \mathrm{~s}$ from parents grown at $25^{\circ} \mathrm{C}$. $\mathbf{d}$, e Changes ( $\mathrm{Log}_{2}$ ) in gene expression in F1s from infected P0s compared to F1s from P0s grown at $25^{\circ} \mathrm{C}$ (left) and F1s from POs grown at $25^{\circ} \mathrm{C}$ compared to F1s from P0s grown at $25^{\circ} \mathrm{C}$ (right) for: (d) genes previously identified as intergenerationally upregulated when parents grown at $25^{\circ} \mathrm{C}$; (e) genes intergenerationally upregulated both when parents were grown at $25^{\circ} \mathrm{C}$ and in the prde- 1 mutant

important new insights into this, first by demonstrating that environmental conditions modulate the piRNA pathway in the germline to establish gene expression changes both in animals exposed to the perturbation and in their offspring, and second by showing that gene expression changes induced in this manner influence fitness over a limited number of generations (Fig. 6). 

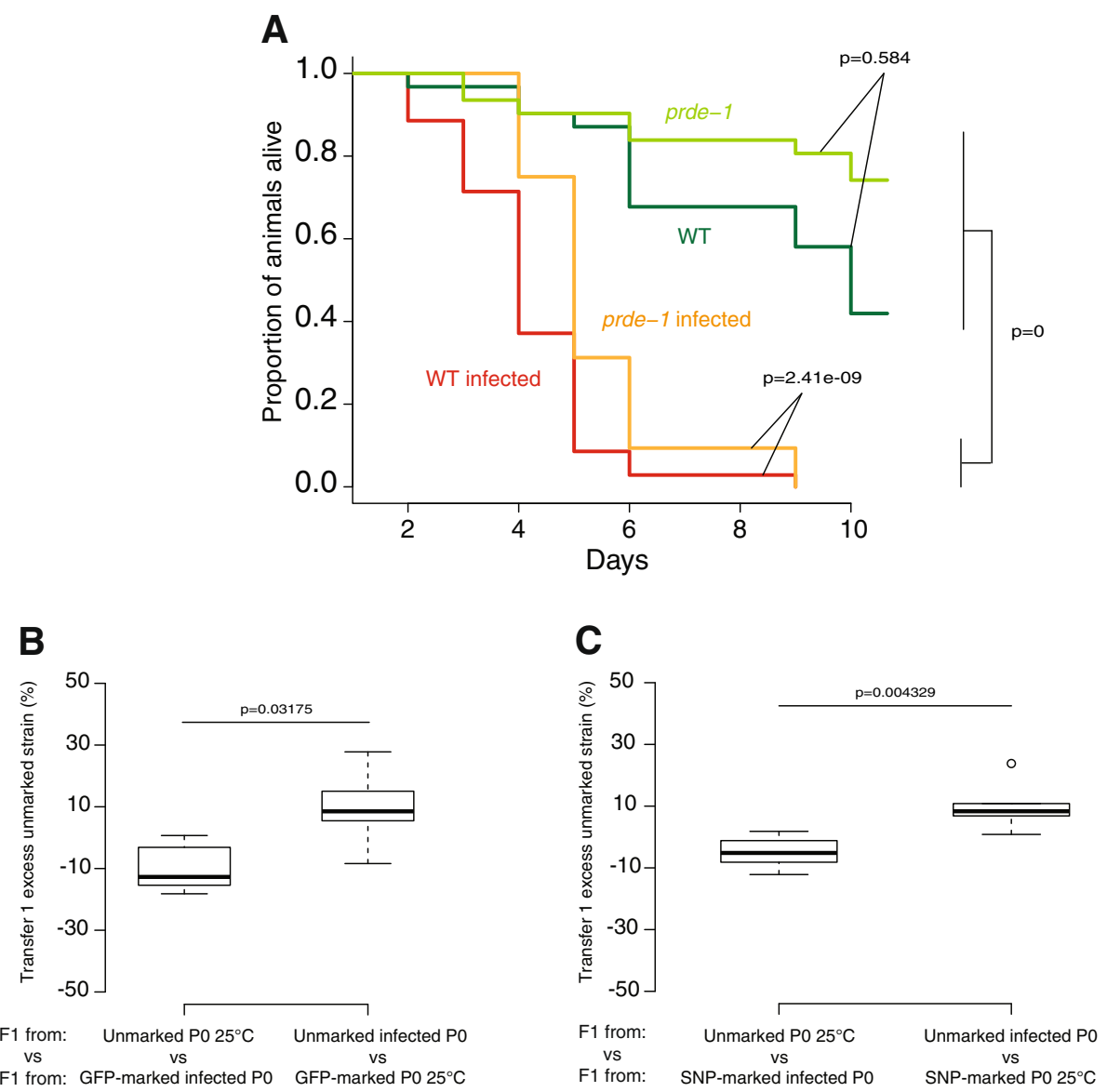

Fig. 5 Bacterial infection improves fitness in subsequent generations. a Survival of the wild-type strain (WT) and the prde- 1 mutant at $25^{\circ} \mathrm{C}$ on regular food (dark green and light green) and on the pathogenic bacteria Serratia marcescens (red and orange). A Mantel-Haenszel Logrank test has been used to assess the significativity between the different treatments. Raw data are available in Additional file 9: Table S4. b Intergenerational competition at $20^{\circ} \mathrm{C}$ between animals derived from (left) unmarked PO animals grown on E. coli at $25^{\circ} \mathrm{C}$ and GFP-marked animals grown on S. marcescens at $25^{\circ} \mathrm{C}$; (right) GFP-marked PO animals grown on E. coli at $25^{\circ} \mathrm{C}$ and unmarked animals grown on S. marcescens at $25^{\circ} \mathrm{C}$. c Intergenerational competition at $20^{\circ} \mathrm{C}$ between animals derived from (left) unmarked PO animals grown on E. coli at $25^{\circ} \mathrm{C}$ and SNP-marked PO animals grown on S. marcescens at $25^{\circ} \mathrm{C}$; (right) SNP-marked PO animals grown on E. coli at $25^{\circ} \mathrm{C}$ and unmarked P0 animals grown on S. marcescens at $25^{\circ} \mathrm{C}$. Y-axes for b and $\mathbf{c}$ show the percentage of unmarked animals after 2-3 generations (1 transfer, all biological replicates), corrected for the effect of the SNP or GFP marker as in Fig. 3. Raw data are available in Additional file 5: Table S2

Modulation of C. elegans piRNA biogenesis in response to the environment

Environmental effects on the effects of small RNA pathways in C. elegans have been observed previously (e.g. $[4,5,33])$. Our study shows for the first time that, despite the constitutive requirement for the piRNA pathway in normal germline function, environmental conditions can directly modulate piRNA biogenesis. Interestingly, our work shows that different stresses (temperature and bacterial infection) have opposite effects on piRNA levels, raising the possibility that there exist mechanisms to directly signal the effect of environmental changes to the piRNA biogenesis machinery. It is possible that the germline may directly sense changes in temperature to modulate piRNA biogenesis. However, importantly, the pathogenic bacteria we studied infect the C. elegans gut
[34], implying the existence of a mechanism to transmit signals between the soma and the germline. The identity of this signalling method is still unclear; it does not appear to involve the canonical stress-signalling axis in $C$. elegans as pmk-1 mutants do not show a difference in mature piRNA levels (Additional file 2: Figure S2D). Establishing the identity of any such sensing mechanism is an interesting prospect for future work; its existence would additionally strengthen the possibility that stress responses could regulate piRNA biogenesis in other species.

\section{Intergenerational epigenetic inheritance in the environment}

Our finding that environmental stimuli can modulate the piRNA pathway provides important new insights 

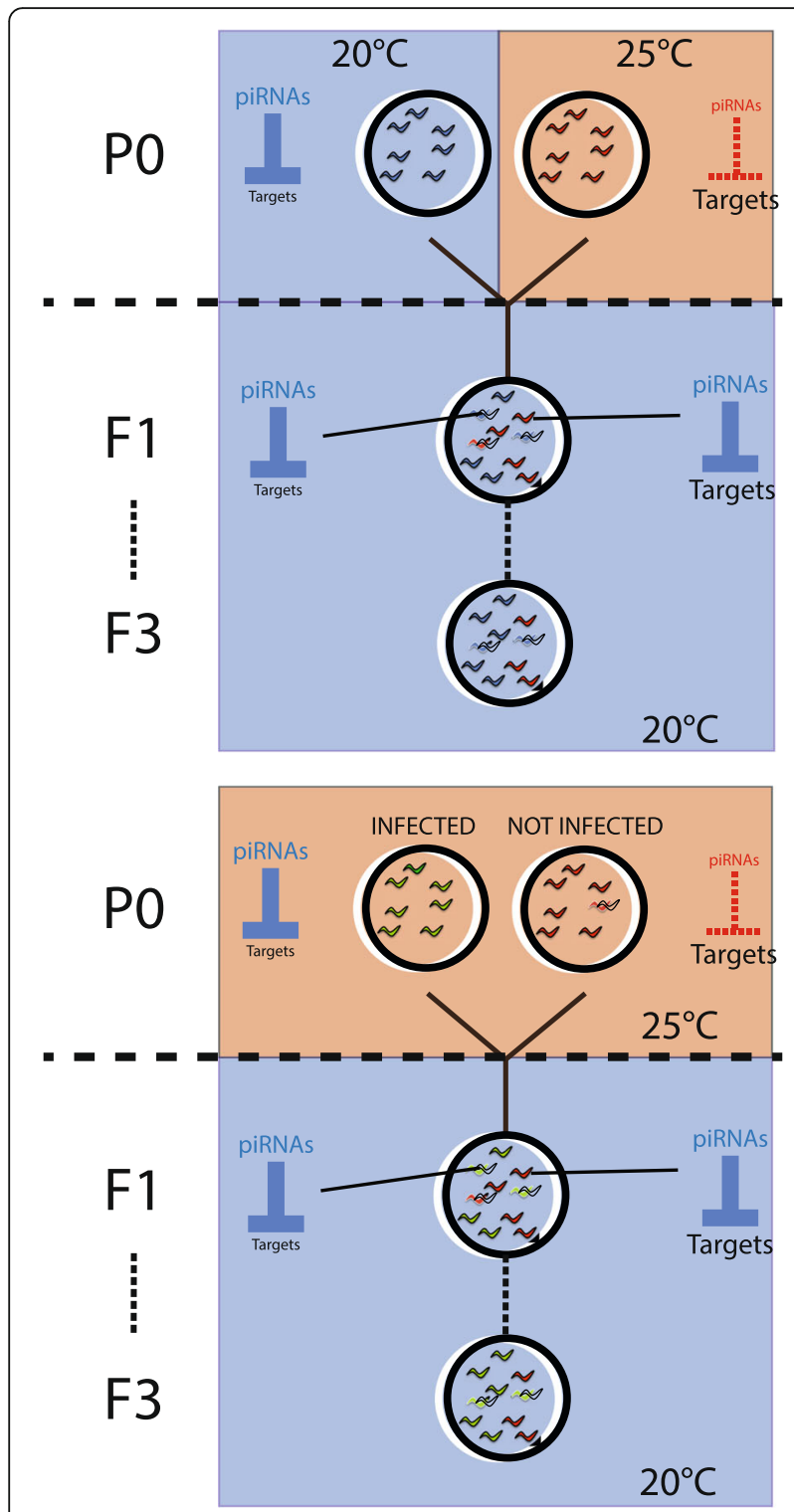

Fig. 6 Environmental conditions affect piRNA biogenesis and fitness intergenerationally in C. elegans. PiRNA biogenesis is reduced at $25^{\circ} \mathrm{C}$ compared to $20^{\circ} \mathrm{C}$ leading to an increase of piRNA targeted genes. The increase of expression of certain genes observed in parental animals grown at $25^{\circ} \mathrm{C}$ and resulting from the loss of piRNAs is maintained in the progeny even if grown at $20^{\circ} \mathrm{C}$. Descendants of animals grown at $25^{\circ} \mathrm{C}$ display a decrease in fitness at $20^{\circ} \mathrm{C}$ compared to descendants of animals grown at $20^{\circ} \mathrm{C}$ or animals grown at $25^{\circ} \mathrm{C}$ on pathogenic bacteria

into the elusive functions of multi-generational epigenetic inheritance in C. elegans. We demonstrate that a moderate increase in temperature leads to loss of motif-dependent piRNA silencing. Some of these changes result in sustained gene expression alterations and also resulted in a loss of fitness in subsequent generations returned to $20{ }^{\circ} \mathrm{C}$. To our knowledge, this is the first direct demonstration of an intergenerational effect in $C$. elegans that has a fitness consequence under physiological conditions.

The reduced fitness at $20^{\circ} \mathrm{C}$ as a result of parental exposure to higher temperature appears to be limited to around 1-3 generations post exposure (Fig. 3 and Additional file 6: S4). Nevertheless, it seems surprising that natural selection has not eliminated this effect. The N2 laboratory strain that we used for our experiments has adapted to the laboratory under relatively constant conditions over multiple generations; thus, it is possible that the responses we observe are laboratory adaptations specific for animals mostly raised at constant temperature. Our observation that similar temperature-dependent responses in several strains of $C$. briggsae and in P. pacificus (Additional file 2: Figure $\mathrm{S} 2$ ), both of which were introduced into the laboratory much more recently than $\mathrm{N} 2$, argues that this is not a C. elegans-specific laboratory adaptation. Instead, we suggest that an interesting possible explanation is raised by our observation that bacterial infection suppresses the temperature-dependent reduction in piRNA levels and leads to intergenerational increase in fitness relative to uninfected animals. We propose that in the natural environment of C. elegans, raised temperature will increase the growth rate of bacteria, many of which will be pathogenic to C. elegans [35]. Thus, in the natural environment of $C$. elegans, increased temperature may usually be accompanied by increased infection, so the intergenerational fitness cost of growth at higher temperature is never visible to natural selection. This suggests that C. elegans is adapted to chronic pathogen infection, representing a nematode equivalent of the famous "hygiene hypothesis" used to explain the incidence of allergy and autoimmune diseases in human populations [36]. It also presents the possibility that many other multi-generational epigenetic effects may be the result of the artificial environment of the organism under laboratory conditions and not usually visible to natural selection in wild populations.

\section{Conclusion}

Here, we show that the C. elegans piRNA pathway responds to alterations in environmental conditions. Temperature decreases piRNA levels but bacterial infection increases it, and these alterations set up gene expression changes that persist into the next generation despite removal of the initial environmental stimuli. Importantly, at least in the case of bacterial infection, it is likely that the environmental effect on the piRNA pathway must be mediated by signalling from the soma to the germline. Additionally, we show, for the first time, potential fitness consequences of the dynamic changes in piRNA levels. Our work acts as a starting point for further exploration of the role of multi-generational epigenetic changes for $C$. elegans in its natural environment. 


\section{Methods}

\section{Nematode strains}

The N2 strain of Caenorhabditis elegans is considered as the wild-type (WT) strain.

The strain SX1316 (mjIs144 II) expresses a piRNA sensor which is off in presence of specific piRNAs and on in absence of those piRNAs. The strains SX1888 and SX2470 also express this sensor but carry prg-1(n4357)I and prde-1(mj207) $V$, respectively. The strain SX2499 carries the prde-1(mj207) $V$ mutation. SX328, used for the completion assay, carries the transgene mjIs17 IV resulting in the expression of GFP in the pharynx. JU2196 is an introgression of the centre of Chromosome IV from the wild isolate JU1580 into the WT background (mfIR41(IV,JU1580>N2). Animals were grown on NGM plates with Escherichia coli HB101.

Pristionchus pacificus (PS312) and Caenorhabditis briggsae (AF16) were maintained on HB101 on NGM plates.

SX328 was obtained from CGC.

\section{Bacterial strains used for infections Pseudomonas aeruginosa}

PA14 and PAK were used as infectious and non-infectious strains, respectively. Each strain was first streaked onto a $10-\mathrm{cm} \mathrm{LB}$ agar plate and incubated at $37{ }^{\circ} \mathrm{C}$ for 12 to $16 \mathrm{~h}$. We then inoculated a single colony into $5 \mathrm{ml} \mathrm{LB}$ broth and incubated at $37{ }^{\circ} \mathrm{C}$ with aeration for 12 to $16 \mathrm{~h}$. We seeded $250 \mu \mathrm{l}$ of the culture on specific Slow Killing plates and incubated them at $37{ }^{\circ} \mathrm{C}$ for $24 \mathrm{~h}$. We finally transferred the plates to $25^{\circ} \mathrm{C}$ for $24 \mathrm{~h}$ before using them.

\section{Photorabdus luminescens}

Preparation of plates was as for $P$. aeruginosa except $30{ }^{\circ} \mathrm{C}$ was used instead of $37{ }^{\circ} \mathrm{C}$ and the final seeding was made onto NGM plates.

\section{Serratia marcescens}

DB11 was used as an infectious strain. It was first streaked onto a $10-\mathrm{cm} \mathrm{LB}$ agar plate and grown at $37{ }^{\circ} \mathrm{C}$ overnight. We then inoculated a single colony into $5 \mathrm{ml}$ LB broth and incubated at $37{ }^{\circ} \mathrm{C}$ with aeration for 12 to $16 \mathrm{~h}$. We seeded $100 \mu \mathrm{l}$ of the culture on NGM plates and incubated them at $37{ }^{\circ} \mathrm{C}$ Overnight. We finally transferred the plates to $25{ }^{\circ} \mathrm{C}$ overnight before using them.

\section{Temperature and infection assays}

\section{Basic temperature assay}

For visual examination of sensor silencing, 5-10 L4 animals were put onto plates at either $20{ }^{\circ} \mathrm{C}$ or $25{ }^{\circ} \mathrm{C}$ and left for $16 \mathrm{~h}$ to lay embryos. Adults were then removed, leaving embryos to hatch and reach adulthood.
Animals were then mounted onto slides, and GFP was visualised using a fluorescent microscope.

For sequencing experiments, populations were synchronised by extracting embryos using sodium hypochlorite treatment ("bleaching") and hatching embryos to L1s overnight in M9 medium. Between 100 and 200 L1s were placed on NGM plates at $20{ }^{\circ} \mathrm{C}$ or $25{ }^{\circ} \mathrm{C}$. Once they reached early adulthood, animals were harvested and washed with M9 for RNA sequencing experiments.

\section{Intergenerational temperature assay}

Populations were synchronised by extracting embryos using sodium hypochlorite treatment ("bleaching") and hatching embryos to L1s overnight in M9 medium. Two plates containing 100 to 200 arrested L1s were put at $20^{\circ} \mathrm{C}$ or $25^{\circ} \mathrm{C}$. Once animals reached early adulthood, they were harvested, washed three times with M9, and either RNA was extracted or animals were treated with hypochlorite solution. L1s resulting from the hypochlorite treatment were then grown at $20{ }^{\circ} \mathrm{C}$ and collected as young adults.

\section{Basic infection assays}

Populations were synchronised by extracting embryos using sodium hypochlorite treatment ("bleaching") and by hatching embryos to L1s overnight in M9 medium. Between 100 and $200 \mathrm{~L} 1 \mathrm{~s}$ were placed on NGM plates at $20{ }^{\circ} \mathrm{C}, 25^{\circ} \mathrm{C}$ or at $25^{\circ} \mathrm{C}$ in the presence of Serratia marcescens, Pseudomonas aeruginosa or Photorabdus luminescens. Once they reached early adulthood, animals were either mounted on slides and observed using a fluorescent microscope or were harvested and washed with M9 for further RNA sequencing experiments.

\section{Intergenerational infection assay}

Populations were synchronised by extracting embryos using sodium hypochlorite treatment ("bleaching") and by hatching embryos to L1s overnight in M9 medium. Two plates containing 100 to 200 arrested L1s were put at $20{ }^{\circ} \mathrm{C}, 25{ }^{\circ} \mathrm{C}$ or at $25{ }^{\circ} \mathrm{C}$ in the presence of Serratia marcescens. Once animals reached early adulthood, they were harvested, washed three times with M9, and either RNA was extracted or animals were treated with hypochlorite solution. L1s resulting from the hypochlorite treatment were then grown at $20{ }^{\circ} \mathrm{C}$ and collected as young adults.

\section{Time course temperature assay}

Cultures were synchronised as previously described. Between 100 and 200 arrested L1s were then plated onto NGM plates at $20{ }^{\circ} \mathrm{C}$. Once they reached adulthood, animals were treated once more with hypochlorite solution. Arrested L1s resulting from hypochlorite treatment of adults were plated onto NGM plates and grown either at 
$20{ }^{\circ} \mathrm{C}$ or $25{ }^{\circ} \mathrm{C}$. Upon reaching early L4 stage, animals were collected in M9 every $2 \mathrm{~h}$ for the treatment at $20{ }^{\circ} \mathrm{C}$ or every $1.5 \mathrm{~h}$ for the treatment at $25{ }^{\circ} \mathrm{C}$. Collected animals were then washed and put into Trizol before RNA extraction and small RNA library preparation.

\section{Competition assays}

The competition assay was performed as described [37] with minor modifications. For each different experiments, each of the two tested strains' embryos (SX238 vs N2 or N2 vs JU2196) were extracted using hypochlorite treatment ("bleaching") and hatched overnight in M9 medium to give synchronised L1 larvae. L1s were then plated on each of the tested conditions in parallel $\left(20^{\circ} \mathrm{C}\right.$ vs $25^{\circ} \mathrm{C}$ or $25^{\circ} \mathrm{C}$ vs DB11 infection) to give the starting population (P0). One day after they reached adulthood, embryos were isolated by bleaching, hatched to L1s overnight and plated onto the final condition of the competition to give the F1 generation. To initiate the competition assay, 10 progeny from each P0 condition (F1s) were put to compete with $10 \mathrm{~F} 1 \mathrm{~s}$ of the other strain from the same or a different parental condition so that each combination of two strains and two parental conditions were represented. Five days later and every 2 days subsequently, animals were collected from plates in M9 and 200-400 transferred onto a new NGM plate. The remaining animals were frozen in $\mathrm{M} 9$ at $-20{ }^{\circ} \mathrm{C}$ for subsequent analysis of SNP proportions (WBVar01650008), or analysed for fluorescent protein expression by microscopy. Thus, the sample taken at transfer 1 corresponds to a mixture of generations F2 and F3 and samples at transfer 2 corresponds to a mixture of generations F3 and F4. Sample sizes for the fluorescent protein analysis are available in Additional file 5: Table S2.

The proportion of each SNP was assessed by pyrosequencing, using a PyroMark Q96 ID instrument from Biotage (Uppsala, Sweden). Five microlitres of the frozen sample was mixed for a Worm Lysis into $45 \mu$ of buffer containing proteinase $\mathrm{K}$ at $100 \mu \mathrm{g} / \mathrm{ml}$. In order to verify whether the measurement of proportions were correct, we also prepared lysis containing different proportions of the two parental strains $(100 \%, 80 \%, 60 \%, 50 \%, 40 \%$, $20 \%$ and $0 \%$ ). We added $2 \mu \mathrm{l}$ of worm lysate to $23 \mu \mathrm{l}$ of PCR mix composed of $12.5 \mu \mathrm{l}$ of Quick-Load ${ }^{\oplus}$ Taq $2 \mathrm{X}$ Master Mix from NEB, $0.1 \mu$ l of non-biotinylated reverse primer (cgccagggttttcccagtcacgacattctgcaacaaaaaaaattaagc) at $10 \mathrm{mM}, 0.4 \mu \mathrm{l}$ of corresponding universal biotinylated primers (biotin-cgccagggttttcccagtcacgac) at $10 \mathrm{mM}$, and $0.5 \mu \mathrm{l}$ of the forward primer (accctaaaaaaacccgataaaatt) at $10 \mathrm{nM}$. Single-stranded DNA was then purified, and the pyrosequencing reaction was performed following the manufacturer's indications using the appropriate sequencing primer (cagtaaagtctcaacaaatg).

\section{Data analysis}

Both strain combinations have minor differences in baseline fitness. We thus corrected for this by subtracting the proportion of $\mathrm{N} 2$ when competing at $25{ }^{\circ} \mathrm{C}$. The corrected proportion of $\mathrm{N} 2$ was then tabulated alongside growth condition of parental strain (infection or treatment with elevated temperature). We then compared conditions using an unpaired two-sample Wilcoxon test. Raw data is available as supplemental Additional file 5: Table S2.

\section{Longevity assay on S. marcescens}

N2 and SX2499 cultures were synchronised with hypochlorite solution. L1s were grown at $25{ }^{\circ} \mathrm{C}$ until they reached early L4 stage. Ten animals were transferred into five plates containing HB101 and five plates containing DB11 for a total of 50 animals per treatment per strain. Every day for 10 days, each animal's death was reported. Animals that disappeared or were found stuck on the plastic border of the plate were excluded from the analysis. During the egg-laying period, animals were transferred to a new plate every day. We used the survdiff function (Mantel-Haenszel Logrank test) from the survival package from R-Cran for statistical analysis. Raw data is available as Additional file 9: Table S4.

\section{RNA extraction}

Once harvested, animals were washed three times in M9 and we extracted RNA using Trizol $^{\circ}$ (Invitrogen) (5-10 vol : vol of pelleted worms). The extraction product was suspended in $20 \mu \mathrm{l}$ in RNAse-free $\mathrm{dd}_{2} \mathrm{O}$.

\section{Small RNA library preparation Decapping RNA}

We added 1 to $5 \mu \mathrm{g}$ of total RNA to a mix containing $1.5 \mu \mathrm{l}$ RNA 5' Pyrophosphohydrolase (RppH,NEB), $2 \mu \mathrm{l}$ of NEB buffer 2 and $\mathrm{H}_{2} \mathrm{O}$, up to $20 \mu$ lotal reaction volume. The final mix was incubated at $37^{\circ} \mathrm{C}$ for $1 \mathrm{~h}$ and cooled down at $4{ }^{\circ} \mathrm{C}$ for $2 \mathrm{~min}$. RNA was then purified using a phenol-chloroform extraction protocol.

\section{Adapter ligation, retrotranscription, amplification and purification steps}

We used the TruSeq ${ }^{\circ}$ Small RNA Library Preparation Kits from Illumina, and adapter ligation, retrotranscription, amplification and purification were performed following the manufacturer's indication. The quantity and the quality of the libraries were then evaluated using Qubit $^{\circ}$ technology from Qiagen and the Tape Station ${ }^{\circ}$ technology from Agilent Technologies.

\section{Data analysis}

Fastq files of small RNAs were processed and mapped to piRNAs using exact matches and identifying piRNA 
precursors with extensions at the $5^{\prime}$ and $3^{\prime}$ end using custom perl scripts, as described previously [17]. piRNA loci in P. pacificus and C. briggsae were predicted by aligning small RNA sequencing reads to the respective genomes (WB235) and identifying 21U-RNAs with a GTTTC sequence between 40 and 50 nucleotides upstream. Statistical tests of differences in reads from piRNA loci were performed using the Wilcoxon paired test with two tails, as this does not assume normal distributions. To compare motif-dependent and motif-independent piRNAs whilst controlling for the different numbers of loci (Additional file 1: Figure S1D and E), > 500 random samples of motif-independent piRNA loci using the $\mathrm{R}$ function sample were made with the size of the sample equal to the number of motif-independent loci detected with at least one read in at least one sequencing run. We then compared reads within this subsample at $20^{\circ} \mathrm{C}$ versus $25{ }^{\circ} \mathrm{C}$ to test whether we observed a reduction at $25^{\circ} \mathrm{C}$ using a Wilcoxon unpaired test with one tail (as we are expecting the sample to approximate to the observed decrease across all reads). We also compared the differences across all sampled loci to the differences across motif-independent piRNA loci testing whether the difference in sampled motif-dependent piRNAs was larger than the difference in motif-independent piRNA loci, again using a Wilcoxon unpaired test with one tail.

Mappings to miRNAs were carried out by using exact matches to the mature sequences of $C$. elegans miRNAs extracted from miRbase (www.mirbase.org) using a custom perl script. 22G RNAs were aligned to protein coding genes using bowtie, allowing for 0 mismatches and reporting only one match per read. DESeq was used to normalise data across replicates and identify statistically significant differences using the negative binomial test [38].

\section{RNA sequencing}

Paired-end non-directional polyA RNAseq libraries were sequenced on an Illumina Hiseq. Reads were mapped directly to a combined file containing coding sequences (WS235) and repeat consensus sequences (Repbase) using bowtie 2 and processed to give counts per sequence using a custom perl script. We used DESeq to obtain normalised counts for each library and identified genes and TEs changing significantly $(p<0.05)$ according to the negative binomial test either between two independent replicates of young adults at $20{ }^{\circ} \mathrm{C}$ and $25{ }^{\circ} \mathrm{C}$ (experiment 1$)$ or consistently changing $(p<0.05)$ at 8 , 16 and $24 \mathrm{~h}$ after the onset of the L4 stage between $20^{\circ}$ $\mathrm{C}$ and $25{ }^{\circ} \mathrm{C}$ (experiment 2). Genes changing significantly in both experiment 1 and experiment 2 were defined as the high-confidence set of genes for further analysis to examine how they changed in $\mathrm{prg}-1 \mathrm{com}-$ pared to WT (mean across 8, 16 and 24 h after the onset of the L4 stage), prde-1 compared to WT (mean across
8, 16 and $24 \mathrm{~h}$ after the onset of the $\mathrm{L} 4$ moult) and in progeny grown at $20{ }^{\circ} \mathrm{C}$ from parents grown at $25{ }^{\circ} \mathrm{C}$ compared to in progeny grown at $20{ }^{\circ} \mathrm{C}$ from parents grown at $20{ }^{\circ} \mathrm{C}$. Raw fastq files have been uploaded to the SRA (SRP145566).

\section{Additional files}

\begin{abstract}
Additional file 1: Figure S1. Change in $22 \mathrm{G}$ small RNA from other pathways at $25^{\circ} \mathrm{C}$. (A) Comparison of total $22 \mathrm{G}$-RNAs at $20^{\circ} \mathrm{C}$ and $25^{\circ} \mathrm{C}$. The $p$ value is a Wilcoxon unpaired test (two tailed). (B) Comparison of miRNA reads at $20^{\circ} \mathrm{C}$ and $25^{\circ} \mathrm{C}$. The $p$ value is a Wilcoxon unpaired test (two tailed). (C) Change in piRNA levels between $20^{\circ} \mathrm{C}$ and $25^{\circ} \mathrm{C}$ normalised by the miRNA reads observed in (B). $p$ value is a Wilcoxon unpaired test (two tailed). (D) Comparison of expression of motif-independent piRNA between $20^{\circ} \mathrm{C}$ and $25^{\circ} \mathrm{C}$. $p$ value is a Wilcoxon unpaired test (two tailed). (E) Histogram of the $p$ value for a reduction in motif-dependent piRNAs at $25{ }^{\circ} \mathrm{C}$ relative to $20^{\circ} \mathrm{C}$ over multiple samples of motif-dependent piRNAs with the same size as the number of motif-independent piRNAs detected. The $p$ value is a Wilcoxon-unpaired test for a reduction (one tailed). (F) Histogram reporting the $p$ value for the change in motif-dependent piRNAs at $25^{\circ} \mathrm{C}$ relative to $20^{\circ} \mathrm{C}$ being larger than the change in motif-independent piRNAs over multiple samples of motif-dependent piRNAs with the same size as the number of motif-independent piRNAs detected. The $p$ value is a Wilcoxon-unpaired test for a larger difference in motif-dependent piRNAs (one tailed). (PDF $2121 \mathrm{~kb}$ )
\end{abstract}

Additional file 2: Figure S2. piRNA production in different species and in the pmk-1 mutant. (A) $\log _{2}$ ratio of the count of $21 \mathrm{U}$ small RNA in $P$. pacificus between $25^{\circ} \mathrm{C}$ and $20^{\circ} \mathrm{C}$. piRNAs, identified by the presence of a conserved upstream motif, are reduced relative to all other 21U-RNAs. 4956 such loci were detected and used for analysis. (B) Difference in motif-dependent piRNA precursors at $25^{\circ} \mathrm{C}$ and $20^{\circ} \mathrm{C}$ in P. pacificus. (C) Ratio of the amount of motif-dependent piRNAs at $20^{\circ} \mathrm{C}$ over $25^{\circ} \mathrm{C}$ in 4 different strains of C. briggsae. AF16 is the standard laboratory strain. In red are tropical strains and in blue are temperate strains. 2431 such piRNA loci were detected in the reference strain AF16 and used for analysis. (D) $\log _{2}$ reads per million of motif-dependent piRNAs in the wild-type (WT) strain and in the pmk-1 mutant at $20^{\circ} \mathrm{C}$ and $25^{\circ} \mathrm{C}$. (E) Change in prg-1 mRNA level between $20^{\circ} \mathrm{C}$ and $25^{\circ} \mathrm{C}$. (PDF $536 \mathrm{~kb}$ )

Additional file 3: Table S1. Genes identified as consistently changed at $25^{\circ} \mathrm{C}$ compared to $20^{\circ} \mathrm{C}$. (PDF $368 \mathrm{~kb}$ )

Additional file 4: Figure S3. Transgenerational alterations in gene expression induced by temperature. (A) Overlap between the change in gene expression at $25^{\circ} \mathrm{C}$ compared to $20^{\circ} \mathrm{C}$ in PO (experiment 1) and the change in gene expression at $25^{\circ} \mathrm{C}$ compared to $20^{\circ} \mathrm{C}$ during the time course experiment (experiment 2). (B) Overlap between temperature-sensitive genes (grey) identified in (A), prde-1-dependent genes (blue) and prg-1-dependent genes (pink). (C) Overlap between temperature-sensitive genes in parents (grey), altered genes in prde- 1 mutants (blue) and altered genes in $\mathrm{F} 1$ grown at $20^{\circ} \mathrm{C}$ from parents grown at $25^{\circ} \mathrm{C}$ (orange). (PDF $409 \mathrm{~kb}$ )

Additional file 5: Table S2. Proportions of the different strains from the competition experiments. (PDF 392 kb)

Additional file 6: Figure S4. Limited duration of temperature-dependent intergenerational fitness effects. (A) Intergenerational Competition on E. coli at $25^{\circ} \mathrm{C}$ between animals derived from (left) P0 animals grown at $25^{\circ} \mathrm{C}$ marked with GFP and unmarked PO animals grown at $20^{\circ} \mathrm{C}$; (right) unmarked PO animals grown at $25^{\circ} \mathrm{C}$ and $\mathrm{PO}$ animals grown at $20^{\circ} \mathrm{C}$ marked with GFP. Y-axis shows the percentage of unmarked animals grown after 2-3 generations (1 transfer, 5 biological replicates per condition), corrected for the effect of GFP at $25^{\circ} \mathrm{C}$. (B) Intergenerational competition on E. coli at $20^{\circ} \mathrm{C}$ between animals derived from (left) unmarked $\mathrm{PO}$ animals grown on E. coli at $20^{\circ} \mathrm{C}$ and GFP-marked PO animals grown at $25^{\circ} \mathrm{C}$ (right) GFP-marked PO animals grown at $20{ }^{\circ} \mathrm{C}$ and unmarked $\mathrm{PO}$ animals grown at $25{ }^{\circ} \mathrm{C}$. Y-axis shows the percentage of unmarked animals after 2-3 generations (1 transfer, 5 biological replicates per condition), 
corrected for the effect of GFP at $25^{\circ} \mathrm{C}$. (C) Multi-generational competition on E. coli at $25^{\circ} \mathrm{C}$ between animals derived from (left) unmarked PO animals grown at $20^{\circ} \mathrm{C}$ and SNP-marked parents grown at $25^{\circ} \mathrm{C}$ (right) SNP-marked PO animals grown at $20^{\circ} \mathrm{C}$ and unmarked parents grown at $25^{\circ} \mathrm{C}$. Y-axis shows the percentage of unmarked animals after 3-4 generations ( 2 transfers, 5 biological replicates per conditions), corrected for the effect of the SNP at $25^{\circ} \mathrm{C}$. (D) Multi-generational competition on E. coli at $20^{\circ} \mathrm{C}$ between animals derived from (left) unmarked PO animals grown on $E$. coli at $25^{\circ} \mathrm{C}$ and SNP-marked PO animals grown on S. marcescens at $25^{\circ} \mathrm{C}$ (right) SNP-marked PO animals grown on E. coli at $25^{\circ} \mathrm{C}$ and unmarked PO animals grown on S. marcescens at 25C. $Y$-axis shows the percentage of unmarked animals after 3-4 generations ( 2 transfers, 5 biological replicates per conditions), corrected for the effect of the SNP at $25^{\circ} \mathrm{C}$. (XLSX $44 \mathrm{~kb}$ )

Additional file 7: Table S3. Raw data from infection experiments. (XLSX $45 \mathrm{~kb}$ )

Additional file 8: Figure S5. Intergenerational alterations in gene expression induced by bacterial infection. Changes in gene expression in F1 s from infected P0s compared to F1s from P0s grown at $25^{\circ} \mathrm{C}$ (left) and F1s from POs grown at $25^{\circ} \mathrm{C}$ compared to F1s from P0s grown at $20^{\circ} \mathrm{C}$ (right) for: (A) genes previously identified as intergenerationally down-regulated when parents grown at $25^{\circ} \mathrm{C}$; (B) genes intergenerationally upregulated when parents grown at $25^{\circ} \mathrm{C}$ but not up-regulated in the prde- 1 mutant. (XLSX $40 \mathrm{~kb}$ )

Additional file 9: Table S4. Raw data from sunvival experiments. (XLSX $42 \mathrm{~kb})$

\section{Acknowledgements}

We thank the members of the Sarkies laboratory for helpful discussions. We thank Marie-Anne Felix's laboratory and Eric Miska's laboratory for sharing the SNP-marked and GFP-marked strains respectively. We thank Jonathan Ewbank for providing Serratia marcescens. We thank Luke Allsop and Alain Filoux for the assistance with Pseudomonas aeruginosa infections. We thank Hinrich Schulenburg for providing strains of Photorabdus luminescens. Some strains were obtained from the Caenorhabditis Genetics Centre (CGC).

\section{Funding}

This work was funded by a grant from the Medical Research Council (Transgenerational Epigenetic Inheritance and Evolution). PS is funded by an Imperial College Research Fellowship. PJ was funded by a Genetics Society Summer studentship.

\section{Availability of data and materials}

High-throughput sequencing data has been submitted to the SRA (SRP SRP145566). C. elegans strains used are available from the Caenorhabditis Genetics Centre. Computer code for processing sequencing data is available on request.

\section{Authors' contribution}

TB and PS performed experiments and experimental data analysis. PS and PJ participated in the computational analysis of high-throughput sequencing data. PS and TB wrote the manuscript. All authors have read and approved the final manuscript.

\section{Ethics approval and consent to participate}

Not applicable.

\section{Competing interests}

The authors declare that they have no competing interests.

\section{Publisher's Note}

Springer Nature remains neutral with regard to jurisdictional claims in published maps and institutional affiliations.

Received: 18 June 2018 Accepted: 30 August 2018

Published online: 18 September 2018

\section{References}

1. Heard E, Martienssen RA. Transgenerational epigenetic inheritance: myths and mechanisms. Cell. 2014;157(1):95-109.
2. Eggert H, Kurtz J, Buhr MFD-D. Different effects of paternal transgenerational immune priming on survival and immunity in step and genetic offspring. Proc R Soc B 2014;281(1797):20142089-9.

3. Radford EJ, Ito M, Shi H, Corish JA, Yamazawa K, Isganaitis E, et al. In utero undernourishment perturbs the adult sperm methylome and intergenerational metabolism. Science 2014;345(6198):1255903-3.

4. Rechavi O, Houri-Ze'evi L, Anava S, WSS G, Kerk SY, Hannon GJ, et al. Starvation-induced transgenerational inheritance of small RNAs in C. elegans. Cell. 2014;158(2):277-87.

5. Schott D, Yanai I, Hunter CP. Natural RNA interference directs a heritable response to the environment. Sci Rep. 2014:4:7387.

6. Ni JZ, Kalinava N, Chen E, Huang A, Trinh T, Gu SG. A transgenerational role of the germline nuclear RNAi pathway in repressing heat stress-induced transcriptional activation in C. elegans. Epigenetics Chromatin. 2016;9:3.

7. Aravin AA, Hannon GJ, Brennecke J. The Piwi-piRNA pathway provides an adaptive defense in the transposon arms race. Science. 2007;318(5851):761-4.

8. Juliano C, Wang J, Lin H. Uniting germline and stem cells: the function of Piwi proteins and the piRNA pathway in diverse organisms. Annu Rev Genet. 2011:45(1):447-69.

9. Ashe A, Sapetschnig A, Weick E-M, Mitchell J, Bagijn MP, Cording AC, et al. piRNAs can trigger a multigenerational epigenetic memory in the germline of C. elegans. Cell. 2012;150(1):88-99.

10. Shirayama M, Seth M, Lee H-C, Gu W, Ishidate T, Conte D Jr, et al. piRNAs initiate an epigenetic memory of nonself RNAin the C. elegans. Germline Cell. 2012;150(1):65-77.

11. Luteijn MJ, van Bergeijk P, Kaaij LJT, Almeida MV, Roovers EF, Berezikov E, et al. Extremely stable Piwi-induced gene silencing in Caenorhabditis elegans. EMBO J. 2012;31(16):3422-30

12. de Vanssay A, Bougé A-L, Boivin A, Hermant $C$, Teysset L, Delmarre $V$, et al. Paramutation in Drosophila linked to emergence of a piRNA-producing locus. Nature. 2012;490(7418):112-5.

13. Batista PJ, Ruby JG, Claycomb JM, Chiang R, Fahlgren N, Kasschau KD, et al. PRG-1 and 21U-RNAs interact to form the piRNA complex required for fertility in C. elegans. Mol Cell. 2008;31(1):67-78.

14. Das PP, Bagijn MP, Goldstein LD, Woolford JR, Lehrbach NJ, Sapetschnig A, et al. Piwi and piRNAs act upstream of an endogenous siRNA pathway to suppress Tc3 transposon mobility in the Caenorhabditis elegans Germline. Mol Cell. 2008:31(1):79-90.

15. Ruby JG, Jan C, Player C, Axtell MJ, Lee W, Nusbaum C, et al. Large-scale sequencing reveals 21U-RNAs and additional MicroRNAs and endogenous siRNAs in C. elegans. Cell. 2006;127(6):1193-207.

16. Kasper DM, Wang G, Gardner KE, Johnstone TG, Reinke V. The C. elegans SNAPC component SNPC-4 coats piRNA domains and is globally required for piRNA abundance. Dev Cell. 2014;31(2):145-58

17. Weick EM, Sarkies P, Silva N, Chen RA, Moss SMM, Cording AC, et al. PRDE-1 is a nuclear factor essential for the biogenesis of Ruby motif-dependent piRNAs in C. elegans. Genes Dev. 2014;28(7):783-96.

18. Gu W, Lee H-C, Chaves D, Youngman EM, Pazour GJ, Conte D Jr, et al. CapSeq and CIP-TAP identify pol II start sites and reveal capped SmallRNAs as C. elegans piRNA Precursors. Cell. 2012;151(7):1488-500.

19. Sapetschnig A, Sarkies P, Lehrbach NJ, Miska EA. Tertiary siRNAs mediate paramutation in C. elegans. PLoS Genet. 2015;11(3):e1005078.

20. de Albuquerque BFM, Placentino M, Ketting RF. Maternal piRNAs are essential for germline development following de novo establishment of endo-siRNAs in Caenorhabditis elegans. Dev Cell. 2015;34(4):448-56.

21. Phillips CM, Brown KC, Montgomery BE, Ruvkun G, Montgomery TA. piRNAs and piRNA-dependent siRNAs protect conserved and essential C. elegans genes from misrouting into the RNAi pathway. Dev Cell. 2015;34(4):457-65.

22. Bagijn MP, Goldstein LD, Sapetschnig A, Weick EM, Bouasker S, Lehrbach NJ, et al. Function, targets, and evolution of Caenorhabditis elegans piRNAs. Science. 2012;337(6094):574-8.

23. Weick E-M, Miska EA. piRNAs: from biogenesis to function. Development. 2014;141(18):3458-71.

24. Hellwig S, Bass BL. A starvation-induced noncoding RNA modulates expression of dicer-regulated genes. Proc Natl Acad Sci. 2008;105(35):12897-902.

25. Sarkies P, SELKIRK ME, Jones JT, Blok V. Boothby T, Goldstein B, et al. Ancient and novel small RNA pathways compensate for the loss of piRNAs in multiple independent nematode lineages. PLoS Biol. 2015:13(2):e1002061.

26. Houri-Ze'evi L, Korem Y, Sheftel H, Faigenbloom L, Toker IA, Dagan Y, et al. A tunable mechanism determines the duration of the transgenerational small RNA inheritance in C. elegans. Cell. 2016;165(1):88-99. 
27. Billi AC, Freeberg MA, Day AM, Chun SY, Khivansara V, Kim JKA. Conserved upstream motif orchestrates autonomous, germline-enriched expression of Caenorhabditis elegans piRNAs. Copenhaver GP, editor. PLoS Genet. 2013; 9(3):e1003392.

28. de Albuquerque BFM, Luteijn MJ, Cordeiro Rodrigues RJ, van Bergeijk P, Waaijers S, Kaaij LT, et al. PID-1 is a novel factor that operates during $21 \mathrm{U}$ RNA biogenesis in Caenorhabditis elegans. Genes Dev. 2014;28(7):683-8.

29. Goh WSS, Seah JWE, Harrison EJ, Chen C, Hammell CM, Hannon GJ. A genome-wide RNAi screen identifies factors required for distinct stages of $C$. elegans piRNA biogenesis. Genes Dev. 2014;28(7):797-807.

30. Kudlow BA, Zhang L, Han M. Systematic analysis of tissue-restricted miRISCs reveals a broad role for microRNAs in suppressing basal activity of the $C$ elegans pathogen response. Mol Cell. 2012;46(4):530-41.

31. Ren Z, Ambros VR. Caenorhabditis elegans microRNAs of the let-7family act in innate immune response circuits and confer robust developmental timing against pathogen stress. Proc Natl Acad Sci. 2015;112(18):E2366-75.

32. Timmons L, Fire A. Specific interference by ingested dsRNA. Nature. 1998; 395(6705):854

33. Simon M, Sarkies P, Ikegami K, Doebley A-L, Goldstein LD, Mitchell J, et al. Reduced insulin/IGF-1 signaling restores germ cell immortality to Caenorhabditis elegans Piwi mutants. Cell Rep. 2014;7(3):762-73.

34. Nicholas HR, Hodgkin J. Responses to infection and possible recognition strategies in the innate immune system of Caenorhabditis elegans. Mol Immunol. 2004:41(5):479-93.

35. Schulenburg H, Félix M-A. The natural biotic environment of Caenorhabditis elegans. Genetics. 2017:206(1):55-86.

36. Bach J-F. The hygiene hypothesis in autoimmunity: the role of pathogens and commensals. Nat Rev Immunol. 2017;18(2):105-20.

37. Ashe A, Bélicard T, Le Pen J, Sarkies P, Frézal L, Lehrbach NJ, et al. A deletion polymorphism in the Caenorhabditis elegans RIG-I homolog disables viral RNA dicing and antiviral immunity. elife. 2013;2:e00994.

38. Anders $\mathrm{S}$, Huber W. Differential expression analysis for sequence count data. Genome Biol. 2010;11(10):R106.

Ready to submit your research? Choose BMC and benefit from:

- fast, convenient online submission

- thorough peer review by experienced researchers in your field

- rapid publication on acceptance

- support for research data, including large and complex data types

- gold Open Access which fosters wider collaboration and increased citations

- maximum visibility for your research: over $100 \mathrm{M}$ website views per year

At BMC, research is always in progress.

Learn more biomedcentral.com/submissions 